\title{
Classical Ehlers-Danlos syndrome: clinical, Histological and ultrastructural aspects
}

\author{
Síndrome de Ehlers-Danlos clássica: aspectos clínicos, histológicos e \\ ultraestruturais
}

\author{
Eduardo de Barros Coelho Bicca ${ }^{1}$ \\ Giselle Martins Pinto ${ }^{3}$ \\ Hiram Larangeira de Almeida Jr ${ }^{5}$
}

\author{
Fabiano Bonow de Almeida ${ }^{2}$ \\ Luis Antônio Suíta de Castro ${ }^{4}$
}

\begin{abstract}
A 12-year-old boy with difficulty in wound healing and scars of unusual appearance was examined. Thin, shiny and protruding skin, characterizing pseudotumoral lesions, was observed on his knees and elbows. Loose joints and increased skin elasticity were also observed. Light microscopy showed rare collagen bundles and loosely dispersed collagen fibers. Irregularly distributed elastic tissue was observed, and transmission electron microscopy revealed disorganized collagen fibers. In cross sections under high magnifications, fibers of varying diameters could be seen, as well as an irregular fiber outline. Scanning electron microscopy of the dermis showed disorganized collagen fibers, which were rarely arranged in bundles. Isolated and crossed-over fibers were also found.

Keywords: Collagen type V; Ehlers-Danlos syndrome; Microscopy, electron, scanning; Microscopy, electron, scanning transmission

Resumo: Paciente masculino de 12 anos relatou dificuldade em cicatrizar, seguido por cicatrizes de aspecto infrequente. A pele dos joelhos e cotovelos é fina, brilhante e protrusa, caracterizando pseudo-tumores. Além disso apresenta hiperelasticidade cutânea e articular. A microscopia óptica demonstrou raros feixes colágenos, as fibras colágenas encontram-se dispersas. O tecido elástico está presente e secundariamente irregular. A microscopia eletrônica de transmissão também observou fibras colágenas desorganizadas e com cortes transversais em grande aumento evidenciou diâmetros variados e contorno irregular das mesmas. A microscopia eletrônica de varredura da derme demonstrou raros feixes colágenos e fibras colágenas isoladas e entrecruzadas.

Palavras-chave: Colágeno tipo V; Microscopia eletrônica de transmissão; Microscopia eletrônica de varredura; Síndrome de Ehlers-Danlos
\end{abstract}

\section{INTRODUCTION}

Collagen is an abundant structural protein found in all animals. In humans it comprises one third of total proteins, makes up three quarters of the dry weight of the skin and is the most prevalent component of the extracellular matrix. ${ }^{1}$

Twenty-eight different types of collagen composed of 46 different polypeptide chains have been identified in vertebrates, and many other proteins contain collagenous domains. ${ }^{1}$

Collagen molecules are synthesized, secreted into the extracellular space and organized in fibrils that are in turn organized into tissue-specific macroaggregates. $^{2}$

The central pathogenesis of Ehlers-Danlos syndrome (EDS) results from defects in collagen. Mutations were identified in structural collagen genes,

Received on 15.09.2010.

Approved by the Advisory Board and accepted for publication on 25.11.2010.

Study carried out as part of the graduate program in health and behavior, Catholic University of Pelotas (UCPEL), Pelotas, RS, Brazil.

Conflict of interest: None / Conflito de interesse: Nenhum

Financial funding: None / Suporte financeiro: Nenhum

Holder of a master's degree in health and behavior - Professor of Pathology, Catholic University of Pelotas (UCPEL) - Pelotas (RS), Brazil.

Biologist - Recipient of a grant for undergraduate research, Catholic University of Pelotas (UCPEL) - Pelotas (RS), Brazil.

Dermatologist - Third year resident, Santa Casa de Misericórdia Porto Alegre - Porto Alegre (RS), Brazil.

Holder of a master's degree in agronomy - Head of the electronic microscopy laboratory, EMBRAPA CPA-CT Pelotas ( Brazilian Agency for Agricultural Research) - Pelotas (RS), Brazil.

Habilitated Professor (Livre Docente) - Assistant Professor, Federal University of Pelotas (UFPel) - Associate Professor of Dermatology, Catholic University of Pelotas (UCPEL) - Pelotas (RS), Brazil 
as well as in genes coding for proteins involved in the processing of this protein. ${ }^{3}$

The hypothesis that EDS is a disorder of fibrillar collagen metabolism is well supported by the identification of specific defects in the collagen biosynthetic pathway that result in clinically different EDS forms. ${ }^{4}$

Three fundamental mechanisms of disease are known to produce EDS: a deficiency of collagen-processing enzymes, dominant negative effects of mutant collagen alpha-chains and haploinsufficiency. ${ }^{4}$

With recent advances, a simplified classification of EDS (Villefranche nosology, 1997) was suggested in which the disorder was divided into six main types. ${ }^{5}$ This classification substitutes the old one, which consisted of nine types (type I to type IX), and is broken down into the following types: classical (previously types I and II); hypermobility (previously type III); vascular (previously type IV) kyphoscoliotic (previously type VI A/B); arthrochalasis (previously type VII A/B) and dermatosparaxis (previously type VII C). ${ }^{5}$ Types $\mathrm{V}$ and VIII and the autosomal recessive type with a tenascin $\mathrm{X}$ deficiency are very rare and, as yet, insufficiently characterized. ${ }^{3,7}$

The classical, hypermobility, vascular and arthrochalasic types all possess a dominant autosomal inheritance, whereas the kyphoscoliotic and dermatosparaxis types are autosomal recessive. ${ }^{6}$ Approximately $90 \%$ of EDS patients have either the classical or hypermobility type, while less than $10 \%$ have the vascular type. ${ }^{8}$ The other three types comprise a small percentage of EDS cases. ${ }^{9}$ Men and women of all races are equally affected by the disease. $^{6}$

Skin and joint involvement are very significant, and dermatologists should therefore be aware of this condition. However, the disease can also affect other systems and organs such as blood vessels, eyes and the gastrointestinal tract. ${ }^{3}$

Classic type EDS tends to be the easiest to recognize. ${ }^{9}$ Patients present with different cardinal signs such as articular hypermobility, extremely fragile soft hyperextensible skin, hemosiderotic scars and cutaneous pseudotumors. ${ }^{3,10,11}$ Complications, such as hernias, prolapse of pelvic organs, premature arthritis and cervical insufficiency, may occur. ${ }^{9,12}$

Patients with the classic type have mutations in type V collagen (COL5A1 and COL5A2 genes), presumably because of negative dominant effects. ${ }^{4,5,7,8}$ Nevertheless, two studies showed that haploinsufficiency of COL5A1 may be more common ${ }^{11,13}$.

\section{CASE REPORT}

A 12-year-old boy presented with a complaint of very difficult wound healing, followed by the formation of scars of unusual appearance. The patient also reported loose joints and an increase in skin elasticity.

On examination, innumerable slightly prominent, chestnut-colored scars were observed on the anterior face of his legs. Thin, shiny protruding skin characterizing a pseudotumoral lesion could be seen on the knees and elbows. An ulceration was also observed on the left knee (Figure 1). Nails were normal and varicose veins were found in the ankles. Mosaic-like atrophic scars were observed on his forearms (Figure 2).

The patient's face was normal although there was an excessive number of scars on his forehead. Joints and skin were easily hyperextended (Figure 3). Laboratory tests were normal.

Light microscopy of hematoxylin-eosin stained sections of skin showed an epidermis with a slightly altered contour and ectatic vessels in the papillary and reticular dermis. Rare irregular collagen bundles of various sizes were observed in the reticular dermis, where collagen was mainly found loosely dispersed (Figure 4A). Verhoeff staining showed disorganized elastic tissue (Figure 4B).

Transmission electron microscopy (TEM) also revealed disorganized collagen fibers, which were seen in cross and longitudinal sections in the same field in a non-parallel arrangement (Figure 5A). In cross sections under high magnifications, fibers of varying diameters could be seen, as well as an irregular fiber outline (Figure 5B).

Scanning electron microscopy (SEM) of the dermis showed disorganized collagen fibers, which were rarely arranged in bundles (Figure 6).

Isolated and crossed fibers were also found.

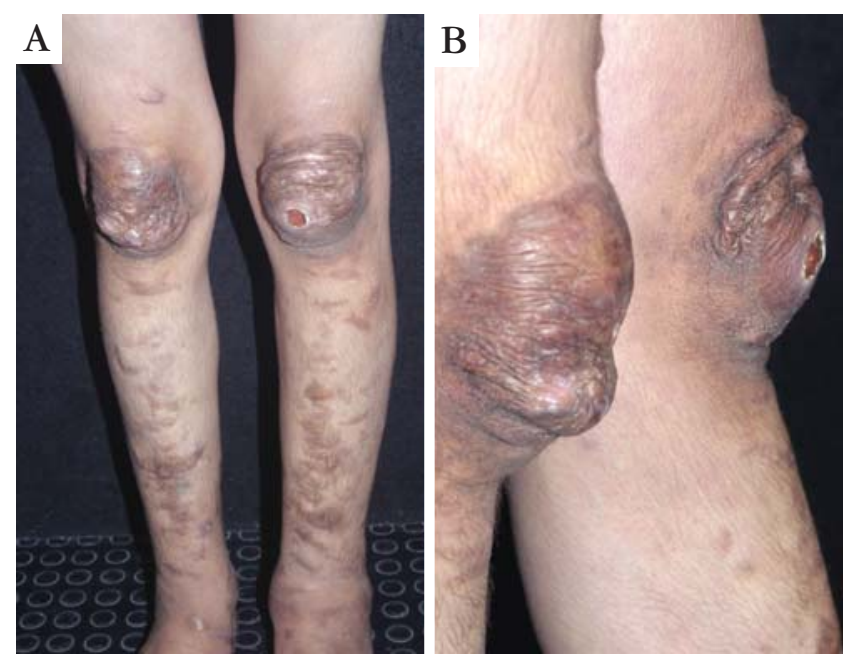

FiguRE 1(A,B): Clinical aspects showing scars on the patient's legs and pseudotumoral lesions on his knees 

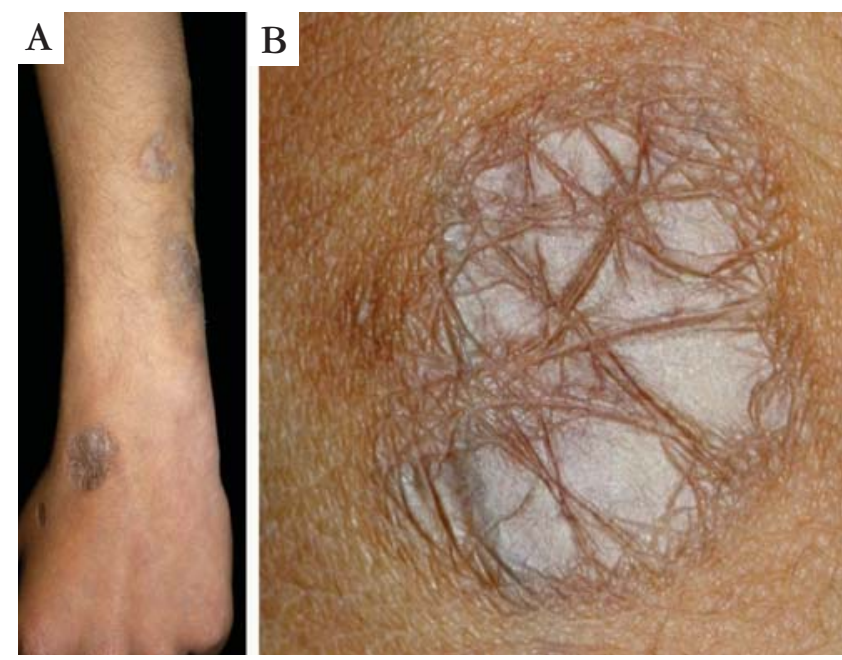

Figure 2 (A,B): Atrophic scars on the patient's forearm. Detail showing a mosaic-like aspect

\section{DISCUSSION}

The Ehlers-Danlos syndrome comprises a group of hereditary disorders of the connective tissue characterized by variable skin hyperelasticity with an increased tendency to abnormal healing. ${ }^{3,7,14}$ In the classic type, patients present with joint hypermobility; extremely fragile, soft, hyperextensible skin; hemosiderotic scars; and cutaneous pseudotumors. ${ }^{3,10,11}$

In the case described here light microscopy revealed skin of normal thickness with loosely arranged collagen fibers and rare organized bundles; elastic tissue was present and disorganized.

Hermmans-Lê et al. described thinner skin and collagen bands and also elastic fibers of various shapes and sizes with a disorganized appearance. ${ }^{14}$ Giunta et al. described some areas with both large and small collagen fibers. They also observed areas with disrupted dermal architecture and agglutinated elastic

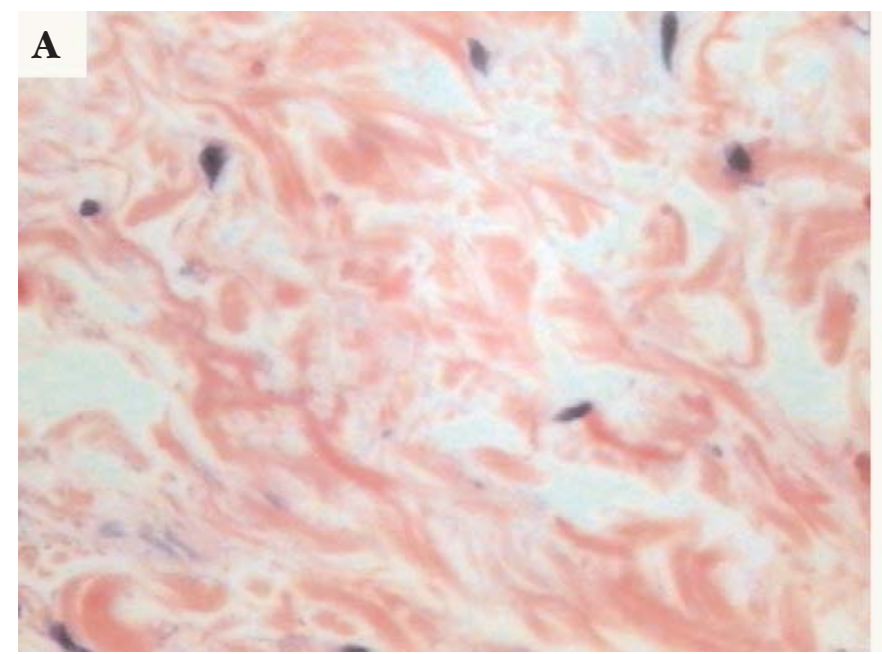

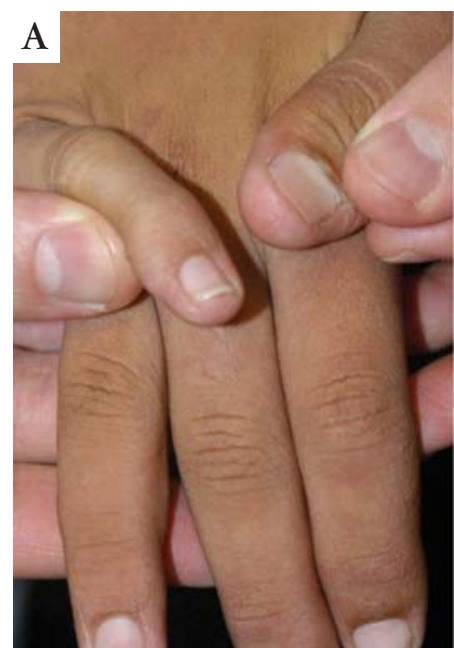

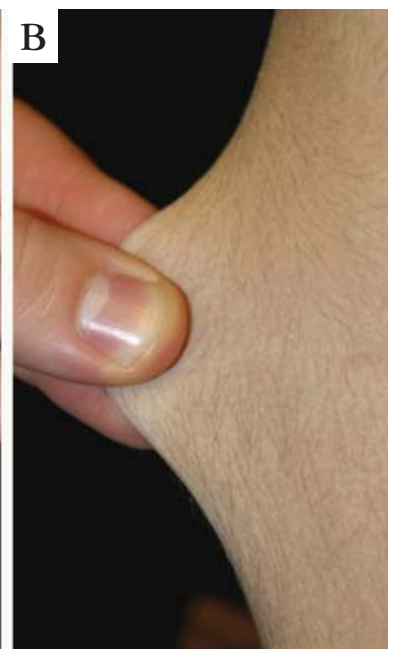

FiguRE 3 (A,B): Skin and joint hyperelasticity

fibers. These elastic changes may be secondary to the collagen disturbance, since the elastic fibers are not primarily affected in EDS. ${ }^{10}$

Similarly to light microscopy, TEM showed disorganized collagen fibers with varying outlines and diameters in the transverse sections. These findings have already been reported in the literature. ${ }^{7}$ Collagen tissue with a cauliflower-like appearance has been reported in the literature but was not found in our case.

SEM also revealed irregularly distributed collagen fibers that did not aggregate well. Isolated and crossed fibers confirmed this abnormal aggregation of collagen. To date only one study using SEM showed this inability of collagen fibers to aggregate. ${ }^{15}$

These histological and ultrastructural findings are similar to those found in the literature and help to elucidate the pathogenesis of this classical dermatological condition.

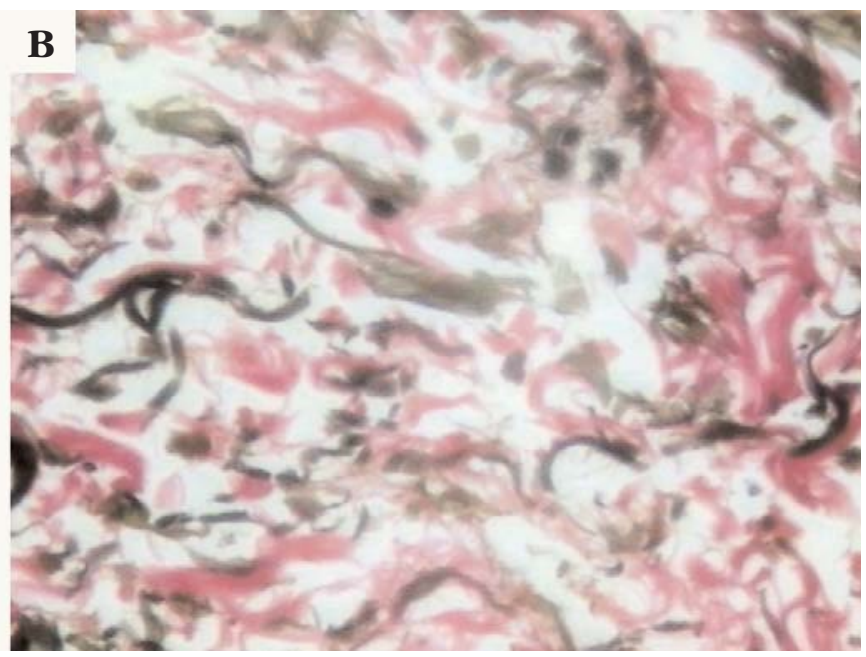

Figure 4: A. Light Microscopy - loose collagen without; regular bundles in the reticular dermis (HE x 400); B. elastic fibers present in the normal quantity but with an irregular distribution (Verhoeff $x 400$ ) 



Figure 5: Transmission electron microscopy- A. disorganized collagen fibers, which were seen in cross and longitudinal sections $(x$ 12,000) $\mathbf{B}$. fibers of varying diameters with irregular outlines(x 85,000)
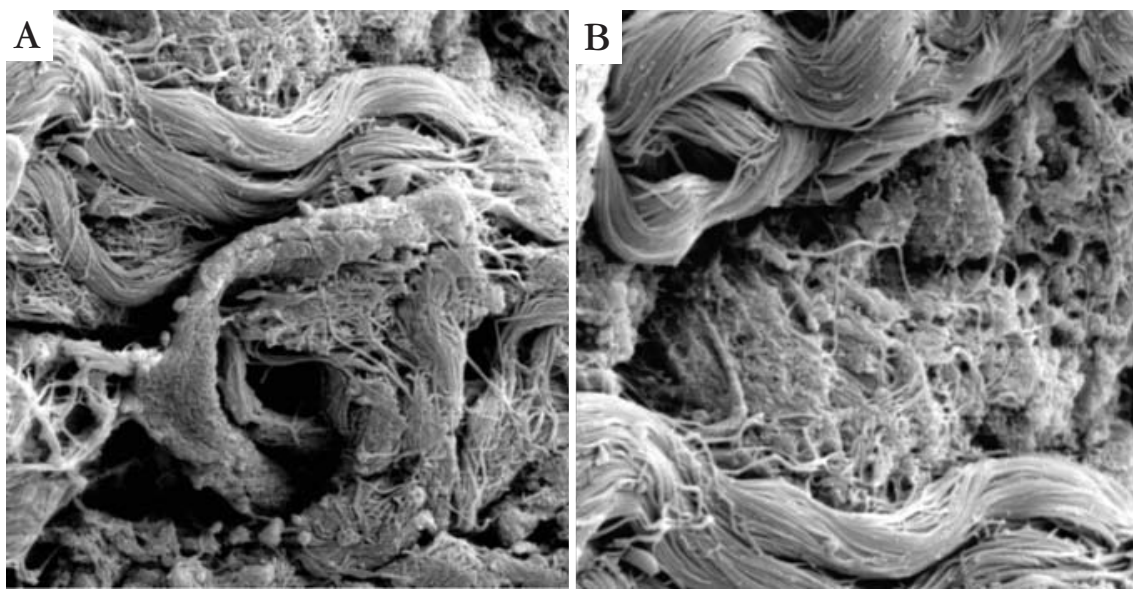

FIGURE 6 (A,B): Scanning Electron

Microscopy - Irregular distribution of dermal collagen fibers, with some arranged in bundles and some isolated (x 3,600)

\section{REFERENCES}

1. Shoulders MD, Raines RT. Collagen Structure and Stability. Annu Rev Biochem. 2009;78:929-58.

2. Birk DE, Fitch JM, Babiarz JP, Doane KJ, Linsenmayer TF. Collagen fibrillogenesis in vitro: interaction of types I and $\mathrm{V}$ collagen regulates fibril diameter. J Cell Sc. 1990;95:649-657.

3. Proske S, Hartschuh W, Enk A, Hausser I. Ehlers-Danlos syndrome-20 years experience with diagnosis and classification at the university skin clinic of Heidelberg. J Deutsch Derm Gesell. 2006:4:308-18.

4. Mao JR, Bristow J. The Ehlers-Danlos syndrome: on beyond collagens. J Clin Invest. 2001;107:1063-9

5. Beighton P, De Paepe A, Steinmann B, Tsipouras P, Wenstrup RJ. Ehlers-Danlos syndromes: revised nosology, Villefranche, 1997. Ehlers-Danlos National Foundation (USA) and Ehlers-Danlos Support Group (UK). Am J Med Genet. 1998; $77: 31-37$

6. Parapia LA, Jackson C. Ehlers-Danlos syndrome-a historical review. Br J Haematol. 2008;141:32-5

7. Nuytinck L, Freund M, Lagae L, Pierard GE, Hermanns-Le T, De Paepe A. Classical Ehlers-Danlos syndrome caused by a mutation in type I collagen. Am J Human Genet. 2000;66:1398-402.

8. Hamel BC. Ehlers-Danlos syndrome. Neth J Med. 2004;62:140-2.

9. Fernandes NF, Schwartz RA. A "hyperextensive" review of Ehlers-Danlos syndrome. Cutis. 2008;82:242-8

10. Giunta C, Nuytinck L, Raghunath M, Hausser I, De Paepe A, Steinmann B. Homozygous Gly530Ser substitution in COL5A1 causes mild classical EhlersDanlos syndrome. Am J Med Genet. 2002;109:284-90.
11. Schwarze U, Atkinson M, Hoffman GG, Greenspan DS, Byers PH. Null alleles of the COL5A1 gene of type $v$ collagen are a cause of the classical forms of Ehlers-Danlos syndrome (types I and II). Am J Med Genet. 2000;66:1757-65.

12. Stoler JM, Oaklander AL. Patients with Ehlers Danlos syndrome and CRPS: a possible association? Pain. 2006;123:204-9.

13. Wenstrup RJ, Florer JB, Willing MC, Giunta C, Steinmann B, Young F, et al. COL5A1 haploinsufficiency is a common molecular mechanism underlying the classica form of EDS. Am J Med Genet. 2000;66:1766-76

14. Hermanns-Lê T, Piérard G, Quatresooz P. Ehlers-Danlos-Like Dermal Abnormalities in Women with Recurrent Preterm Premature Rupture of Fetal Membranes. Am J Dermatopathol. 2005;27:407-10.

15. Black CM, Gathercole LJ, Bailey AJ, Beighton P. The Ehlers-Danlos syndrome: an analysis of the structure of the collagen fibres of the skin. $\mathrm{Br} J$ Dermatol. 1980;102:85-96

MAILING ADDRESS / ENDEREÇO PARA CORRESPONDÊNCIA:

Hiram Larangeira de Almeida Jr

Programa de Pós-Graduação em Saúde e

Comportamento

Universidade Católica de Pelotas

Rua Barroso, 1202 - Pelotas RS

CEP: $96010-280$

E-mail: hiramalmeidajr@hotmail.com

Como citar este artigo/How to cite this article: Bicca EBC, Almeida FB, Pinto GM, Castro LAS, Almeida Jr. HLA. Classical Ehlers-Danlos syndrome: clinical, Histological and ultrastructural aspects. An Bras Dermatol. 2011;86(4 Supl 1):S164-7. 